\title{
THE VANISHING ENGLISH VIRELAI: FRENCH COMPLAINTE IN ENGLISH IN THE FIFTEENTH CENTURY
}

The ballade, the rondeau, and the virelai are the three principal formes fixes of fourteenth- and fifteenth-century French lyric poetry. Alongside these three main forms, poets also experimented with more flexible and varied genres such as the lay and the complainte. Such technical nomenclature implies reliable categories for analysis, yet in reality these three forms (being first dance-songs, then forms for singing, then forms for lyric poetry) underwent a complex evolution, their forms often intertwining, varying, and changing. As Nigel Wilkins gently chides, 'many literary editors and critics would be hard put to it to say exactly what was "fixed" about the formes fixes..$^{1}$ Of the three principal forms, the virelai was the rarest and also the least fixed. Its evolution as a French form is complicated, and its existence in English both as a technical term and as a form in its own right may be deceptive. As Christopher Page has shown, as dance-song forms 'the ballade and virelai were intertwined in the second half of the thirteenth century' and both developed from a structure which he calls 'the ballade-virelai matrix'. ${ }^{2}$ This matrix is exemplified in a large number of songs in the early fourteenth-century chansonnier Oxford, Bodleian Library, MS Douce 308 copied under the heading 'balettes'. These songs have what Page calls a 'protean nature' and are referred to by a range of names. ${ }^{3}$ Though lacking a fixed label and having variable form, all of these songs are 'generated from the principle of alternating verse and refrain (which is the matrix of virelai and ballade) but without the partial recapitulation of the refrain within the verse (which is the matrix of the rondeau)' ${ }^{4}$ In the relevant entry in the New Grove Dictionary, Wilkins teases out the essential difference between the virelais and the ballades in these MS Douce 308 balettes as follows: 'In the virelai the refrain is normally several lines in length and occupies the whole of the first musical section, whereas in the ballade it is most commonly one line in length and appears at the close of the second musical section. ${ }^{5}$

The identity of the virelai solidified somewhat as the ballade, rondeau, and virelai became first forms in which songs for performance (rather than to accompany dancing) were composed and then later evolved into literary forms for lyric poetry. ${ }^{6}$ Machaut, though he did later write a small number of virelais without music, composed a significant number of virelais (both music and text) in the I34Os. Lawrence Earp argues that the majority of these were intended for dancing and that Machaut was 'quite self-consciously preserving this genre for 
the dance', consistently labelling such songs as chanson baladée (meaning 'danced song'). ${ }^{7}$ Machaut's insistence that these were songs for dancing indicates, Earp suggests, that by the 1340 s the virelai had already started to be thought of as a lyric for singing. ${ }^{8}$ As it took shape as a lyric for song but not dance, an underlying consistency of structure emerged. Wilkins defines the fourteenth-century virelai as a musical form thus: 'Its principal features were: the first musical section for the refrain several lines in length; two sets of matching text for the repeated second musical section, usually with first-time (ouvert) and second-time (clos) bars; the return to the first musical section with text to match the rhyme and metre of the refrain; and finally the repetition of the refrain itself.'

This musical origin supplied the structure of the virelai as it evolved from a lyric for singing into a lyric poem never intended to be set to music. The virelai begins with an opening refrain (usually on two rhymes), though extant examples show variety in the number of lines in the refrain, in the refrain's rhyme-scheme, and in the number of syllables in each line. Then there are three sections which make up one 'stanza' (or 'verse' in the musical sense), the first two sections sharing the same structure (corresponding to the twice-repeated second melody in the musical virelai), sometimes using the same rhymes as the refrain and sometimes using different rhymes. Again, surviving examples show variety in rhyme-scheme and line-length. Then the rhyme-scheme and versification of the refrain are repeated in the final part of the three-section 'stanza', though with different words. Finally the refrain is repeated. The virelai can be extended at this point by repeating the pattern of another three-section 'stanza' followed by the refrain and so on. Thus whilst it is categorized as one of the formes fixes of French lyric poetry, the virelai is subject to frequent 'elaboration, extension, [and] intricacy in metre and rhyme'. ${ }^{10}$ This variety may explain the rather obscure account of the virelai given by Eustache Deschamps in his L'Art de dictier which offers a confusing comparison between the virelai and the ballade, in combination with a conflation of terms which refer to musical and textual elements. ${ }^{11}$ Nonetheless, the core elements of the musical structure (as defined by Wilkins above) provided the basis upon which French poets composed virelais with varying degrees of variation and elaboration.

The examples given in Wilkins's One Hundred Ballades, Rondeaux and Virelais anthology illustrate some of the potential variety. ${ }^{12}$ One Machaut virelai takes the form $A A B B A A B$ bba bba aabbaab $A A B B A A B$ and so on for sixty-seven lines (No. 24, 'Plus dure qu'un dÿamant', using lines of seven and four syllables), whilst the other takes the form $A A B A A A B A$ bba bba aabaaaba $A A B A A A B A$ and so on for seventy-four lines (No. 25, 'Dame, à qui', using lines of two, three, and seven syllables). Jean Froissart's 'Moult m'est tart que je revoie' (No. 42) begins in the pattern $A A B B A$ ccd ccd aabab $A A B B A$. The examples Wilkins gives of Christine de Pizan's virelais are closer to Machaut's in form, though she has only the first line of the refrain at each moment of repetition. Christine's 'En ce printemps gracieux' (No. 74) begins $A A B B A A B$ bba bba bbabba $A$, whilst 'Pour Dieu! Ma tres doulce dame' (No. 75) begins with the variation $A A B B A A B \quad c d$ cd aabbaab $A$. Deschamps (No. 6o, beginning 'Sui je, sui je, sui je belle?') simplifies the virelai 
further: $A b b c A b b c A b b c A$ and so on for forty-five lines. Whilst even these few examples show considerable variation, one can nonetheless see that a basic structure (of refrain, three-section 'stanza', then refrain) holds largely true.

Having pinned down the essential characteristics of the French forme fixe virelai, one might then wonder whether this form made its way across the Channel, as the ballade and rondeau certainly did. ${ }^{13}$ In recent years there has been renewed interest in French influence on English writing and in literary relations between England and France in the fourteenth and fifteenth centuries. ${ }^{14}$ Such investigations broaden our sense of fifteenth-century poetic traditions, showing that English poetry continued to be directly inspired by French lyric forms even as the work of Chaucer, Hoccleve, and Lydgate, amongst others, popularized verse in Chaucer's rhyme royal and Monk's Tale stanzas. This article explores the use of the term virelai in modern criticism to label and contextualize certain types of Middle English lyrics. A small group of late medieval English poems have been wrongly labelled as virelai, thus obscuring their true affiliations with other French stanza-forms, namely the French lyric complainte and certain types of narrative verse. The existence of the English virelai may in fact be illusory, with the term used erroneously to give a name to poems in which rhymes from one stanza are carried over into different positions in the following stanza. The mistaken history of the supposed English virelai demonstrates the dangers of contextualizing surviving Middle English lyrics simply by reiterating previous editorial judgements about form or by reference to other examples in the same form within the English canon. It shows that stanza-forms were borrowed directly from French poetry without necessarily being mediated through the verse of Chaucer or his poetic successors. Moreover, to understand such formally innovative lyrics, it is necessary to cast one's net more widely than the (admittedly complex) history of the three principal French formes fixes. This small group of English lyrics responds to the forms of French dits amoreux and also to the stanza-forms of inset lyrics within French narrative poems.

If one were solely to examine lexical evidence, it might seem likely that virelais were written in English in the fourteenth and fifteenth centuries. The Middle English Dictionary defines the Middle English usage of virelai as referring to 'a short poem of several stanzas on two rimes, opening with a refrain which is repeated after every stanza. ${ }^{15}$ This definition loosely corresponds with the essential structure of the French form, though the reference to two rhymes and the repetition of the refrain after every stanza is misleading. In the MED's citations, virelai appears in lists of verse-forms and songs, usually those composed by modish young lovers. Aurelius, the 'lusty squier, servant to Venus' (V.937) who pursues Dorigen in Chaucer's Franklin's Tale, composes 'manye layes, / Songes, compleintes, roundels, virelayes' (V.947f.) about his unrequited love and his inability to express his sorrow. ${ }^{16}$ In Gower's Confessio Amantis, Genius the Confessor personifies the vice of Vainglory as a fashionable neophyte who composes 'caroles ... / Rondeal, balade and virelai' (I.2708f.). ${ }^{17}$ Amans then correspondingly confesses that he has attempted to devise 'Rondeal, balade and virelai' as well as 'Caroles' in order to woo his lady, singing them in hall and in chamber (I.2726-35). It is often unclear whether the reference 
is to the composing of a tune and its lyrics, the setting of a lyric to music, or the writing of a lyric poem never intended to be set to music. These references are generic rather than specific, often exploiting the rhyme potential of virelai (most obviously with lay). It is therefore likely that these collocations are repetitions in translation of similar lists of lyric forms in French texts. The narrator of Machaut's Remede de Fortune, describing his initial period of unrequited love for his lady, passes the time by teaching himself to compose 'chanson et lays, / Baladez, rondeaus, virelays, / Et chans' ('chansons and lais, ballades, rondeaux, virelais, and songs'). ${ }^{18}$ There are similar catalogues in the prologue of Le Livre du chevalier de La Tour Landry, in which Geoffroy lists the compositions which he made for his late wife, and in Jean Froissart's Le Joli Buisson de Jonece. ${ }^{19}$ Such lists in French works could easily be converted into catalogues of song-forms or verse-forms by English writers such as Gower and Chaucer. The technical term virelai was thus recognized in England from the late fourteenth century onwards, but these generalized references should not lead us to assume that the form as practised by Machaut, Christine de Pizan, Froissart, and others was known or imitated in English. It was easy for writers to borrow terms, but this does not guarantee knowledge of the particular characteristics of individual genres of lyric.

A similar scepticism should be applied to critical accounts which suggest that the virelai migrated to England as a practised form rather than simply as an item of vocabulary. Such scepticism is required because of longstanding confusion amongst anglophone critics as to how a virelai might be defined. As U. T. Holmes and C. Scott warn in the Princeton Encyclopedia of Poetry and Poetics: 'one must approach any $\bmod [\mathrm{ern}]$ definition with caution'.$^{20}$ For their anglophone readership, Holmes and Scott define the virelai's structure in musical terms as follows:

It begins with a refrain, followed by a stanza of four lines of which the first two have a musical line (repeated) different from that of the refrain. The last two lines of the stanza return to the music of the refrain. The opening refrain, words and music, is then sung again.

In light both of the virelai's essential structure and its potential for variation, this definition is misleadingly precise. Nonetheless, Holmes and Scott do go on to acknowledge the considerable variety found in virelais by French lyric poets. The Princeton Encyclopedia entry then pinpoints one potential source of confusion for twentieth-century accounts of the virelai in the definitions of the nineteenth-century French prosodist Théodore de Banville. Reasoning by erroneous etymology and attempting to distinguish between the lay and the virelai, de Banville, in his Petit Traité de la poésie française, first outlined a form which he called the 'virelai ancien' (though he cites no medieval examples). ${ }^{21}$ In this virelai ancien, the rhymes are 'turned' (from virer, 'to turn') from one stanza to another, the second rhyme of the first stanza becoming the first rhyme of the second stanza and so on. De Banville drew his etymology and explanation from Michel Mourgeus's seventeenth-century Traité de la poësie françoise. ${ }^{22}$ De Banville provides his own exemplification by extending Mourgeus's example of a lay into a virelai by adding a second stanza in 
which the $b$-rhyme of the first stanza becomes the $a$-rhyme of the second stanza and so on. De Banville's example thus has three nine-line stanzas, composed in short lines in tail-rhyme groups with two five-syllable lines and one two-syllable line in each group of three aabaabaab, the second stanza beginning with the $b$-rhyme of the first. This example, despite its name, has no refrain and its definitive characteristic is rhyme 'turning' from one stanza to another.

It is my hypothesis (a hypothesis which cannot be definitively proved as the scholars in question do not cite a source for their delineation of the virelai) that de Banville's definition and illustration, in a rather imprecise way, provided the rationale for labelling as virelais a number of Middle English poems (and parts of poems) which exhibited rare forms of interchanging rhyme. With no obvious label for such poems from within the English tradition, and no English examples of the virelai available to contradict such an identification, editors and critics borrowed de Banville's notions so as to account for the presence of features otherwise difficult to explain. Walter W. Skeat, in a short article in the 4 March 1893 issue of the Athenaum, defined two sections of Chaucer's Anelida and Arcite (lines 256-7I and 316-32) as the 'sole existing specimens' of the virelais which Alceste reports that Chaucer wrote as hymns for the God of Love's holy days in the Prologue to the Legend of Good Women. ${ }^{23}$ As with the Middle English examples cited above, here the term appears in rhyme-position in a generic list of lyric forms ('balades, roundels, virelayes', F423, G4II) and hence might make us suspicious that Chaucer wrote any virelais at all. Yet ironically it may have been the desire to find extant examples of Chaucer's virelais (and to find a tradition of poems stemming from them) which motivated some of these misidentifications. The passages of Anelida and Arcite which Skeat singled out are part of the section known as Anelida's Complaint, a tour de force of versification..$^{24}$ Both passages cited are pairs of stanzas having the rhyme-scheme aaabaaab bbbabbba. Each stanza is formed of a twice-repeated unit of three octosyllabic lines followed by a fourth decasyllabic line.

In the Athenaum note, Skeat summarized what he took to be the key feature of this form: 'The repetition of the same rhymes in a different order is the essential point in a virelay.' It is likely that Skeat's definition of a virelai also influenced the subsequent Oxford English Dictionary definition of virelay..$^{25}$ Clearly unaware of the basic form of fourteenth- and fifteenth-century French virelais, Skeat most likely drew on de Banville's pseudo-etymological notion that the virelai was defined by rhymes which 'turned' from one stanza to another. Skeat then considered a number of Hoccleve's short poems which had in the previous year been published in F. J. Furnivall's volume of Hoccleve's minor poems for the Early English Text Society. On the basis that they met his definition of a virelai having the same rhymes in a different order, Skeat gave them the label 'virelay'. ${ }^{26}$ These short poems are formed of stanzas of eight lines, each stanza in the form often known as the Monk's Tale stanza following Chaucer's use of this form and called double croisée in an anonymous French ars poetica, Les Règles de la Seconde Rhétorique (written between I4II and I432) ${ }^{27}$ But rather than repeating his three rhyme-sounds in each of the three stanzas in the same positions (as in the conventional ballade), Hoccleve 
rotates his rhymes around each subsequent stanza in various configurations, so that, for example, the first stanza rhymes $a b a b b c b c$ whilst the second stanza rhymes cbcbbaba (with other stanzas having other permutations of the three rhymes within the basic double croisée pattern). In each case, the concluding rhyme of one stanza becomes the opening rhyme of the next.

Skeat called this rotation of rhymes veering, an Anglicization (I suspect) of de Banville's notion that virelai derived etymologically from virer, 'to turn'. When he came to print other Chaucerian works in the supplementary seventh volume (I897) of his Complete Works of Geoffrey Chaucer, Skeat edited a short lyric beginning 'Along walking' under the heading 'Virelai'. ${ }^{28}$ The poem (DIMEV 453) is an anonymous lyric from Cambridge, Trinity College, MS R.I3.19. ${ }^{29}$ Its first-person speaker laments the depths of his lovesickness and sorrow, bewailing the fact his lady dismisses his loyalty with such disdain. Skeat presents the poem's pairs of two short tetrasyllabic lines as one longer line, but the underlying rhyme-scheme is aaabaaab $b b b c b b b c$ and so on for five stanzas. He again refers to the sections of Anelida and Arcite listed above as the 'correct example' of a virelai (thus privileging Chaucer's work as the first and exemplary English instance of this supposed form) and also instructs the reader to compare 'the poem by Lord Rivers, in the same metre'.

This latter poem attributed to Anthony Woodville, Lord Rivers, beginning 'Sumwhat musyng' (DIMEV 4994), had been discussed briefly by Skeat in the first volume of his Works of Geoffrey Chaucer as a comparison for 'Alone walkyng'. ${ }^{30}$ It is a moving first-person lament describing the speaker's wretched and unjust predicament, without hope of legal redress or other remedy, in the face of his imminent execution. ${ }^{31}$ According to John Rous in his Historia regum Anglie (completed in 1486), it was written by Woodville when he was imprisoned in Pontefract Castle in June 1483 on the eve of his execution. ${ }^{32}$ Woodville's poem is composed in short tetrasyllabic lines in eight-line stanzas, rhyming aaabaaab $b b b c b b b c$ etc. The text survives in whole or in part in six witnesses, with a musical setting by Robert Fayrfax. ${ }^{33}$ Skeat calls Rivers's poem 'the Virelai', a label which subsequently influenced the categorization of poems written with similar stanzapatterns. In 1907, H. N. MacCracken edited a hitherto unpublished poem (DIMEV 2147) from a John Shirley manuscript (London, British Library, Add. MS 16165) under the title 'The Earl of Warwick's virelai'. ${ }^{34}$ The poem narrates a lover's pain, his devotion to his lady, her virtues and beauty, his request that she have pity on him, and his intention to remain devoted to her forever. The lyric is written in fifteen four-line stanzas, the first three lines in each stanza being octosyllabic and the fourth line tetrasyllabic. Each stanza rhymes aaab, with the final rhyme of one stanza becoming the initial rhyme of the next: $a a a b b b b c c c c d$ etc. In his prefatory material, MacCracken gives no rationale for giving the poem this label, but we might hypothesize that he relied on Skeat's account of rhymes 'veering' from one stanza to another as the supposed defining characteristic of the virelai.

It is likely that the authority of Skeat's edition of Chaucer led to the naming of certain Middle English lyrics as virelais in the Index of Middle English Verse (1943) compiled by Carleton Brown and Rossell Hope Robbins. ${ }^{35}$ The Supplement to the 
Index of Middle English Verse (1965) compiled by Robbins and John L. Cutler left these labels unchanged and additionally identified 'Sumwhat musyng' as 'A virelai by Earl Rivers ... five 8-line stanzas' (presumably on the basis of Skeat's discussion in his Complete Works of Chaucer), as well as labelling IMEV 353 (beginning 'As Y lay vpon a nyght') as a virelai because it was identified by John Stevens as a carol whose music corresponds to the French virelai song-form. ${ }^{36}$ These labels, unsurprisingly, have found their way into subsequent criticism and editing. ${ }^{37} \mathrm{~A}$ I980 article by Robbins, for example, discusses 'Sumwhat musying' as a virelai, giving the following generous definition of the form: 'With specimens so few, it would be unwise to be dogmatic ..., but apparently the Middle English virelai consists of five stanzas, each rhyming aaabaaab, with each succeeding stanza interlocked with its foregoing, the $b$ rhyme of one becoming the $a$ rhyme of the next. ${ }^{38}$ Most recently, Douglas Gray's contribution to the 2010 Companion to the Middle English Lyric offered a description which relies on Skeat's definition and that of the Oxford English Dictionary: 'virelai, which often consists of stanzas of short lines with two rhymes, the second of which becomes the first and chief rhyme of the following stanza - though there are variations in which this "tail-rhyme" is not carried forward.' This definition repeats earlier approximations, adding in a confusing reference to tail-rhyme for good measure. As the politicians say, the definition of the Middle English virelai is now not fit for purpose. Without this classification, we are left with a small group of poems which share formal features but whose identity and formal allegiances have been obscured by their mislabelling.

The various Hoccleve poems under consideration are best recategorized as experimental ballades. Hoccleve, in his formal preferences, draws as much from his own reading in French poetry as he does from Chaucer. ${ }^{39}$ Hoccleve names the form he uses for these poems as that of 'balade' in his autograph manuscript heading to the Kennington poem. ${ }^{40}$ As J. A. Burrow points out, Hoccleve had a flexible approach to the definition of a ballade, and his ballades do not reproduce the French forme fixe ballade in every respect. ${ }^{41}$ Choosing not to employ a refrain in his ballades, Hoccleve was able to substitute an alternative type of formal complexity, namely the rotation of rhymes around each stanza. These five short poems should thus be more properly considered as experimental ballades in double croisée stanza. This seems to have been Hoccleve's own innovation, though there are somewhat similar experiments with interlocking rhyme in ten-line stanzas in Oton de Granson's Livre Messire Ode which Hoccleve may have known (see the inset lyric complaintes at lines 216-325 and 1872-974)..$^{42}$ Considerable experiment occurred in France and England in the decades either side of the year 1400 as regards mid-fourteenth-century verse-forms, and Hoccleve's unusual ballades should be seen as part of this innovation.

The remaining poems which have been cited as English virelais (the Anelida and Arcite stanzas, the Beauchamp and Woodville poems, and 'Alone walkyng') do draw their inspiration from French verse-forms, but from lyrics other than the virelai. The formal features shared by these poems (namely groups of four or eight lines and the interlocking of rhyme from one stanza to another, with varying line length 
in the first two examples) are rare in English, but they can be contextualized by reference to French stanza-forms, both narrative and lyric forms. They take their forms directly from French poetry, and, in the case of the latter three examples, they do so without relying on Chaucer as an intermediary.

First, we might consider Guillaume de Machaut's Jugement du roy de Behaigne. The poem's editors call the form of its narrative 'semi-stanzaic', comprising 'interlocking quatrains, rhyming $a a a b b b b c c c c d$, etc, with the first three lines of each quatrain decasyllabic and the fourth tetrasyllabic'. ${ }^{43}$ Machaut's semi-stanzaic narrative, both in content and form, was imitated by other French poets. It was employed by Jean Froissart in his Dit dou bleu chevalier, by Christine de Pizan in three poems (Debat de deux amans; Livre des trois jugements; Dit de Poissy), and by Alain Chartier in his Debat des deux fortunés d'amours and in the main text of the Livre des quatre dames. ${ }^{44}$ The Middle English lyric sequence preserved in London, British Library, Harley MS 682, usually attributed to Charles d'Orléans and edited by Mary-Jo Arn under the title Fortunes Stabilnes, begins with a fiftyline verse letter patent (itself a translation of one of Charles's earlier French poems) admitting the lover into the service of Cupid and Venus which is written in this semi-stanzaic form, showing that it could be used as a lyric form as well. ${ }^{45}$ As Barbara K. Altmann (the editor of Christine's three poems in this form) notes, the anonymous French ars poetica treatise called Les Règles de la Seconde Rhétorique names this form as the 'taille ... de 3 et I'. ${ }^{46}$ It is identified as particularly appropriate for 'complaintes amoureuses ou grans lays' and later in the same treatise for 'diz, rommans ou orisons' ${ }^{47}$ Jean Molinet, author of a late fifteenth-century Art de la rhétorique, records it as a form used for 'amoureuses complaintes et autres doleances' and gives an example rhyming aaab $b b b c$ etc. with three octosyllabic lines and a fourth tetrasyllabic tail. ${ }^{48}$ Though these Seconde Rhétorique treatises give this form a name and a subject, their authors may be simply extrapolating from what they found in their reading of Machaut and later poets. Nonetheless, even if the categorization is retrospective, it indicates that the form was sufficiently common as to be recognizable by those interested in identifying French verse-forms in the first half of the fifteenth century.

This French stanza-form seems the most obvious inspiration for the versification of the Beauchamp lyric. The poem is ascribed by its copyist John Shirley to Richard Beauchamp, Earl of Warwick, for whom Shirley worked as secretary. ${ }^{49}$ Shirley, in an addition to his original heading of 'Balade', supplies the information that Beauchamp composed the poem for his second wife, Isabella. ${ }^{50}$ The short time between the death of Beauchamp's first wife Elizabeth Berkeley on 28 December I422 and his marriage to Isabella in November I423, as well as general doubt about Shirley's reliability, has led to some scepticism about the plausibility of this ascription. ${ }^{51}$ Nevertheless, Shirley was copying this section of the manuscript at exactly the right point in the 'early to mid I42Os' to have acquired this text directly from his employer. ${ }^{52}$ Beauchamp (if he was indeed the author) shortens the lines to a combination of three octosyllabic lines and a single tetrasyllabic tail. Despite this prosodic variation, if we see Beauchamp's chosen form as inspired by the 
semi-stanzaic three-and-one stanza of both the jugements or débats amoreux and stand-alone complaintes, Beauchamp reinforces his chosen subject matter with his chosen form, or, conversely, matches his content to his chosen form. His short lyric of sixty-two lines is, as described above, a lover's complaint, less dramatic in its situation than the circumstances of the two candidates for judgement in Machaut's Behaigne (the one a lady whose lover has died and the other a knight whose lady has betrayed him). Yet by selecting the three-and-one form, Beauchamp signals an association with narrative poems by Machaut and Christine de Pizan which use this semi-stanzaic form.

The three-and-one stanza used for both lyric complaintes and narrative dits shares features with French forms used for inset lyrics within longer narratives. Poets composed lyrics for insertion into narrative dits in the three principal formes fixes and also experimented with the more flexible and varied forms of the lay and the complainte. ${ }^{33}$ The lay was usually composed in twelve stanzas, each stanza composed of lines of different lengths and subdivided into halves or quarters. Each stanza was to be different from the others in terms of its rhyme-scheme and line-length pattern, except for the first and last stanzas which were to be identical. The complainte was not usually defined by formal properties but by its subject matter, though it is possible to trace the evolution of particular complainte forms. ${ }^{54}$ A number of Machaut's complaintes, inset into longer narrative poems (Fonteinne amoureuse, Remede de Fortune, Voir dit), were written in a sixteen-line stanza rhyming aaabaaabbbbabbba. ${ }^{55}$ This sixteen-line stanza, known as a seizain, was composed of four sets of three-and-one tail-rhyme units, often combining either three decasyllabic lines and one tetrasyllabic line or three octosyllabic lines and one tetrasyllabic line. Though in Machaut's version the rhymes are not interlocked in the same way as the narrative three-and-one stanza and do not interlink between stanzas, the two halves of this arrangement nonetheless have a point of interchange in which the dominant rhyme of the first eight lines becomes the subsidiary one in the second and vice versa. This verse-form was chosen by Froissart for inset complaintes in two of his narrative dits, namely Le Paradis d'amours and L'Espinette amoureuse, and the complainte de moralite in his Prison amoureuse. ${ }^{56}$ Christine de Pizan wrote two complaintes amoreuses in a related seizain stanza (rhyming aaabbccccddddeee and having three decasyllabic and one tetrasyllabic line in each group of four).$^{57}$ Christine's version of the seizain combines the interlocking rhymescheme of Machaut's Behaigne semi-stanzaic form with the sixteen-line seizain unit, though she does not interlock rhyme between stanzas. Ten of the twelve sections of Alain Chartier's Complainte comprise a single sixteen-line stanza of equal length lines whose rhymes follow Machaut's sixteen-line complainte pattern. ${ }^{58}$ So whilst the complainte could in theory be written in a number of stanza-forms, in practice particular stanza-forms did become particularly associated with the genre, though they were also subject to ongoing experimentation and variation. The complainte also had a distinct poetic identity, that of a first-person lamentation, its repeated rhymes perhaps evoking a lover's painful sorrows and exclamations. Daniel Poirion, in his study of French courtly lyric poetry, notes that poets use the description en 
complainte to designate a poem exhibiting 'le mouvement strophique régulier et monotone', creating 'une certaine langueur'. ${ }^{59}$ The use of only two rhymes across sixteen lines produces this combination of sustained movement yet plangent repetition.

It is the particular sixteen-line complainte stanza-form used by Machaut and others, not only in terms of its verse-form but also in terms of its subject matter and style, which influenced the remaining Middle English lyrics which exhibit 'veering' or interlocking rhyme. Anelida's Complaint, comprising twelve stanzas framed by a prologue and epilogue, appears to have been loosely inspired by the structure of the medieval French lay with its twelve stanzas and varied rhymeschemes. ${ }^{60}$ The two pairs of eight-line stanzas within Anelida's Complaint, if seen as a single continuous stanza, exhibit the same rhyme-scheme as the sixteen-line stanza used by Machaut and others for complaintes. ${ }^{61}$ Chaucer (if he did indeed write these lines) reverses the conventional line-length pattern, having three shorter lines followed by one longer line. This is in keeping with Anelida and Arcite's technical experimentation generally. The experiments with stanza-form here can be compared to the experiments in English with French stanza-forms in Charles d'Orléans's Fortunes Stabilnes. This sequence contains, in the middle section of the work which describes a celebration of the narrator's retirement from love at the Castle of No Care, various short lyrics which represent the after-dinner dancing (lines 4487-637). ${ }^{62}$ One of these lyrics (lines 4505-52) is formed of three sixteen-line complainte stanzas (each stanza having its own rhymes), narrating exactly the sort of stereotypical lover's complaint which characterizes French lyrics in this form. Charles, like Chaucer, drew on his knowledge of French stanza-forms to create variety for his English lyrics in this section of the work. ${ }^{63}$

Rather than combining longer and shorter lines, the stanzas in the Fortunes Stabilnes lyric are composed in tetrasyllabic lines throughout, short lines which perhaps convey a sense of the lover's pained exclamations of distress. This choice of line-length anticipates that of the later fifteenth- and early sixteenth-century versions of the French complainte in English. As the work's editor explains, the manuscript of Fortunes Stabilnes remained in England after Charles's return to France, was copied at least once, and was read by the author of the Assembly of Ladies. ${ }^{64}$ Its influence and circulation may well have been limited, but it is interesting to note that the later fifteenth-century examples of English complainte poems, Woodville's 'Sumwhat musyng' and the Cambridge, Trinity College, MS R.I3.I9 poem beginning 'Alone walkyng', likewise choose the tetrasyllabic line throughout as they develop their own English versions of the French complainte. Their stanza-form could be thought of as one half of the sixteen-line complainte stanza, rhyming aaabaaab and enhanced by interlocking rhymes between stanzas (perhaps inspired by Machaut's Behaigne three-and-one stanza and/or the mid-point moment of rhyme interchange in the longer sixteen-line stanza), the subsidiary rhyme in one stanza becoming the dominant one in the next throughout the lyric. Both are written in lines of four syllables throughout, having abandoned the tailrhyme structure which makes the fourth and eighth lines different from the rest. 
Despite these adjustments, their subject matter links them strongly with the French complainte tradition. 'Alone walkyng' concentrates very intently on the lover's pain, frustration, and despair, giving no clue about any biographical circumstance. 'Sumwhat musyng' adapts the usual conventions of the complainte, in which a lover describes his wretched state as a result of his lady's disdain, into a description of a prisoner's acceptance of his imminent execution, a death which he cannot escape because of Lady Fortune's refusal to alter his fate. Their short line-length and rhythmic and rhyming regularity capture in English verse Poiron's sense of the complainte as a monotone, mournful expression of weariness and distress. 'Alone walkyng' was copied by Linne Mooney's Scribe A, who worked closely with the Hammond scribe in copying the works of Chaucer and Lydgate and thus in establishing the canon of Middle English verse. ${ }^{65}$ Nonetheless the poem shares fol. $16 \mathrm{O}^{\mathrm{r}}$ with a ballade which begins, after a description of the turning of the seasons from February to May, with praise of the daisy and concludes with a lover's description of his devotion to his lady. ${ }^{66}$ As the poem's most recent editor notes, this lyric is inspired by French marguerite poetry. ${ }^{67}$ Though the juxtaposition between the two items may be accidental given their collection in a booklet of short filler items, it may also indicate that the French origins of both pieces may have been recognized and connected.

The form of these later fifteenth-century English complaintes bears witness not only to poets' freedom to experiment as French verse-forms were borrowed into English, but also to other influences on fifteenth-century poetics. It seems likely that Woodville and the author of the Trinity poem were also influenced by (or perhaps themselves influenced) the form of early Tudor songs whose lyrics were written in short, usually tetrasyllabic lines and whose stanzas rhyme aaabaaab or aaabcclb but without the interlocking rhyme between stanzas, each stanza having new rhymes. ${ }^{68}$ As noted above, the Woodville poem survives with a musical setting for three voices by Fayrfax, indicating that its verse-form was deemed suitable for musical arrangement. The Ritson manuscript (London, British Library, Add. MS $5665, c .1470$ to 1500) has one song (with the rhyme-scheme aaabaaab cccdcccd etc.) beginning 'Alone, alone, / Mornyng alone' with music for two voices. ${ }^{69}$ The Fayrfax manuscript (London, British Library, Add. MS 5465, c.1500) has several songs in related forms alongside the Woodville setting $\left(\mathrm{F}_{9}\right.$, one stanza of aaabcccb, likely incomplete, beginning 'Love fayne wolde I'; Fi8, two stanzas of aaabaaab, beginning 'Yowre counturfetyng'; F25, three stanzas of aaabaaab, beginning 'Madame, defrayne!')..$^{70}$ As their first lines suggest, they take (with one exception which will be considered further below) lover's complaints as their subject matter, giving voice to a lover's wretchedness and despair because his lady will not take pity on him. This suggests that this song form retained its association with its likely origin, the French complainte.

The supposed English examples of the French virelai, which are in fact English responses to forms of French lyric complainte and narrative, emphasize to us that French poetry continued to be read and imitated in England even after the influence of Chaucer and Lydgate began to strengthen in the fifteenth century. 
Ardis Butterfield has called attention to 'the profound fascination with French lyric culture in fifteenth-century England' which can be seen both in the layout of fifteenth-century manuscripts of Chaucer's Troilus and Criseyde and in the way in which manuscripts of French lyric collections and sequences were valued amongst noble readers in England. ${ }^{71}$ Such fascination can more easily be tracked codicologically than textually. Other than Fortunes Stabilnes, and the interesting case of Lydgate's Temple of Glas (which uses couplets for narrative description but rhyme royal for speeches and inset lyrics, including one inset ballade), there were few obvious attempts to emulate in English the mixed verse-form combinations of narrative and inset lyrics found widely in French dits amoreux. ${ }^{72}$ But the lyrics discussed herein show that English readers who wanted to try their hand at verse composition sometimes chose French lyric forms above other possibilities. Even as Chaucer, Hoccleve, Lydgate, and others began to establish an English poetic tradition centred on rhyming couplets, and seven- and eight-line stanzas, for certain aristocratic and aspirational readers French lyric forms remained fashionable and preferable.

Whilst we cannot be certain why these poets selected their chosen verse-form, it is notable that both of the attributed authors of these poems can be shown to have had direct contact with French poetry, suggesting acquaintance with French verse-forms and lyric genres. Richard Beauchamp is recorded as one of the owners of the Froissart anthology, Paris, Bibliothèque nationale de France, MS f. fr. 831. ${ }^{73}$ Anthony Woodville inherited London, British Library, Harley MS 443I, a volume containing various works by Christine de Pizan, from his mother, Jacquetta de Luxembourg. ${ }^{74}$ Woodville himself translated Christine de Pizan's Proverbes moraux into decasyllabic couplets, the brief translation being printed by Caxton in February I478..$^{75}$ The Froissart manuscript owned by Beauchamp contains the two dits which have inset complaintes in the sixteen-line stanza. ${ }^{76}$ Likewise, Harley MS 443I contains the two complaintes by Christine in seizains which combine elements of Machaut's sixteen-line complainte stanza and his Behaigne semi-stanzaic form. ${ }^{77}$ It is not the case that each man simply reproduced in the poem attributed to him the form of the complaintes in the manuscript which he owned. But their ownership of such manuscripts indicates that French complainte stanza-forms were known in England and available for experimentation and imitation.

This small group of lyrics demonstrates that the French complainte genre (and its associated stanza-forms), though not widespread, was nonetheless a source of imitation and inspiration in England in the fifteenth century. Perhaps reinforced by the very similar form of certain early Tudor song lyrics, the tetrasyllabic aaabaaab (or the variation $a a a b c c c b$ ) stanza remained popular into the sixteenth century. Three songs attributed to Sir Thomas Wyatt are in this tetrasyllabic aaabccb stanza, and there is a single poem in the same form in London, British Library, Harley MS 2252 (the commonplace book of the London merchant and bookseller John Colyns) beginning 'O mestres why'. ${ }^{78} \mathrm{In}$ each case, this form is used for a first-person complaint, suggesting that the association of this stanzaform with this particular subject matter and mode of expression persisted in the 
first half of the sixteenth century. Thomas Feylde's Controversy between a Lover and a Jay, printed by Wynken de Worde (?1527 and ?1532), begins with a rhyme royal prologue in keeping with its wealth of Chaucerian allusion. ${ }^{79}$ The body of the poem, however, is written in groups of aaab rhymes, entirely in keeping with its subject matter, the discussion between a lover (who begins by lamenting his sorrows in love) and the speaking bird who educates him about the folly of love and warns him in antifeminist fashion about womanly inconstancy. Feylde's work is thus a late English response to the French dit amoreux tradition both in subject and in its choice of verse-form.

The subject matter of these Tudor songs and lyrics (and the initial overheard complaint within Feylde's Controversy) remains that of lovers' lamentations, suggesting that the verse-form retained its essential identity in England. The association between this stanza-form and its conventional subject could also therefore be used meaningfully and ironically to expose the potentially insincere rhetoric used in such male lovers' laments (themselves designed to convey the lover's desperation in order to persuade his lady to take pity on him). This suggests an ongoing awareness of the form's associations amongst poets and their readers. A poem in the late fifteenth-century Findern manuscript beginning 'What-so men seyn', amongst the group which may have been written by women, composed in the tetrasyllabic aaabaaab stanza but without interlocking rhyme, describes how men dissemble in love, using promises and lamentation insincerely and strategically. ${ }^{80}$ William Dunbar, in a poem entitled 'the contempt of blyndit love' in its manuscript witness, likewise selects this same stanza-form for a description of the unreliability of love which advises that it is 'ane pount of ignorance / To lufe in sic distemperance'. ${ }^{81}$ Dunbar emphasizes the formal features of his chosen stanza by having all three of its stanzas rhyme aaabaaab on the same two rhymes (with $a$-lines octosyllabic and $b$-lines tetrasyllabic). One of the Fayrfax manuscript songs mentioned above (FI8, written in short lines in the aaabaaab stanza) likewise accuses male lovers of 'counturfetyng', speaking sweetly but thinking the contrary. ${ }^{82}$ The Findern lyric and Fayrfax song are written from a woman's point of view, asserting that women are all too aware of this deception. The choice of the aaabaaab rhyme-scheme as a vehicle for complaint about male complaint offers a poetic retort or answer to the conventional male lament written in the same stanza-form. Though this verse-form (both the rhyme-interlocking version and the less elaborate variety) is not related to the French virelai but rather to stanza-forms used for complaintes and dits, it nonetheless had identity, currency, and meaning in England in the fifteenth and early sixteenth centuries. Whilst the English virelai is in reality an editorial and critical ghost, the confused creation of well-meaning scholars, these complainte stanzas are alive and well in later Middle English poetry.

St Edmund Hall

University of Oxford

JENNI NUTTALL 


\section{NOTES}

I am very grateful to Medium Avum's editors and their anonymous reviewer for helpful advice on an earlier version of this article. I am also grateful to Philip Knox for informative discussions and suggestions, and indebted to Professor Elizabeth Eva Leach for her patient correction of my initial attempts to define the French virelai.

1 Nigel Wilkins, 'The structure of ballades, rondeaux and virelais in Froissart and in Christine de Pisan', French Studies, 23 (1969), 337-48 (p. 337).

2 Christopher Page, 'Tradition and innovation in BN fr. I46: the background to the ballades', in Fauvel Studies: Allegory, Chronicle, Music, and Image in Paris, Bibliothèque Nationale de France MS français I46, ed. Margaret Bent and Andrew Wathey (Oxford, 1998), pp. 353-94 (p. 372).

3 Ibid., p. 374 .

${ }^{4}$ Ibid.

5 Nigel Wilkins, 'Virelai', in The New Grove Dictionary of Music and Musicians, ed. Stanley Sadie, 20 vols (London, I980), XX, I-3.

${ }^{6}$ On this evolution, see Lawrence Earp, 'Lyrics for reading and lyrics for singing in late medieval France: the development of the dance lyric from Adam de la Halle to Guillaume de Machaut', in The Union of Words and Music in Medieval Poetry, ed. Rebecca A. Baltzer, Thomas Cable, and James I. Wimsatt (Austin, Tex., I99I), pp. IOI-3I.

7 Ibid., p. IIs.

${ }^{8}$ Ibid., pp. IIsf. See also Lawrence Earp, Guillaume de Machaut: A Guide to Research (New York, I995), p. 257 n. 3 I.

9 Wilkins, 'Virelai', p. I, and see also Wilkins, 'Structure', p. 338. Compare the outline of the virelai's essential form in Pierre Bec, La Lyrique française au moyen âge, XII $-X I I^{e}$ siècles: contribution à une typologie des genres poétiques médiévaux: études et textes, 2 vols (Paris, 1977-8), I, 239f., and the discussion and tables in Daniel Poirion's Le Poète et le prince: l'évolution du lyrisme courtois de Guillaume de Machaut à Charles d'Orléans (Paris, 1965), pp. 326-33, 343-8. See also Robert Mullally, 'Vireli, virelai', Neuphilologische Mitteilungen, IOI (2000), 45I-63. 10 Wilkins, 'Structure', p. 344.

11 Eustache Deschamps, L'Art de dictier, ed. and trans. Deborah M. Sinnreich-Levi (East Lansing, Mich., 1994), pp. 44-6, 84f.

12 One Hundred Ballades, Rondeaux and Virelais from the Late Middle Ages, ed. Nigel Wilkins (Cambridge, 1969).

${ }^{13}$ Nigel Wilkins, 'En regardant vers le Païs: the ballade and the rondeau, a cross-Channel history', in England in the Fourteenth Century: Proceedings of the 1985 Harlaxton Symposium, ed. W. M. Ormrod (Woodbridge, 1986), pp. 298-323. For an introduction to the French forme fixe lyrics in English, see Douglas Gray, 'Middle English courtly lyrics: Chaucer to Henry VIII', in A Companion to the Middle English Lyric, ed. Thomas G. Duncan (Cambridge, 2005), pp. 120-49.

${ }^{14}$ Recent examples of such renewed interest include Ardis Butterfield, The Familiar Enemy: Chaucer, Language, and Nation in the Hundred Years War (Oxford, 2009), as well as the essays in Section IV of Language and Culture in Medieval Britain: The French of England, c.II00-C.I50o, ed. Jocelyn Wogan-Browne et al. (Woodbridge, 2009).

${ }_{15} M E D$, s.v. 'virelai', $\mathrm{n}$.

${ }^{16}$ All quotations from Chaucer are from The Riverside Chaucer, ed. Larry D. Benson, 3rd edn (Oxford, 1988).

${ }^{17}$ John Gower, Confessio Amantis, ed. Russell A. Peck with Latin translations by Andrew 
Galloway, 3 vols (Kalamazoo, Mich., 2004), I, I73f.

18 Guillaume de Machaut, 'Le Jugement du roy de Behaigne' and 'Remede de Fortune', ed. James I. Wimsatt and William W. Kibler (Athens, Ga, 1988), pp. I88f. (lines 403-5).

${ }_{19}$ Le Livre du chevalier de La Tour Landry, ed. Anatole de Montaiglon (Paris, I854), p. 2; Jean Froissart, An Anthology of Narrative and Lyric Poetry, ed. and trans. Kristen M. Figg with R. Barton Palmer (New York, 200I), pp. 284f. (lines 45If.).

20 The Princeton Encyclopedia of Poetry and Poetics, ed. Roland Greene et al., 4th edn (Princeton, 2012), p. 1522.

${ }_{21}$ Théodore de Banville, Petit Traité de poésie française (Paris, I88I), pp. 2I6-2I.

22 Michel Mourgues, Traité de la poësie françoise, new edn (Paris, 1729), pp. 246-5I.

23 Walter W. Skeat, 'Chaucer's virelays', Athenaeum, 4 March I893, p. 28I.

${ }^{24}$ Skeat repeats his identification of these lines as 'a virelay' in his notes to lines 256-7I in his edition of The Complete Works of Geoffrey Chaucer, 6 vols (Oxford, I894), I, 536. The editors of Anelida and Arcite in the Riverside Chaucer hedge their bets, describing Chaucer's varying of the rhyme-scheme of these stanzas 'in a way almost to resemble a virelay' (p. 933). On Anelida and Arcite's versification, see Helen Cooper, 'Chaucerian poetics', in New Readings of Chaucer's Poetry, ed. Robert G. Benson and Susan J. Ridyard (Cambridge, 2003), pp. 3I-50 (p. 37), and also Paull F. Baum, Chaucer's Verse (Durham, NC, 196I), pp. 99-IOI. The unity of Anelida and Arcite and its attribution to Chaucer have been seriously questioned by A. S. G. Edwards: 'The unity and authenticity of Anelida and Arcite: the evidence of the manuscripts', Studies in Bibliography, 4I (1988), I77-88. Edwards shows that what we call Anelida and Arcite may in fact represent two poems which have been grafted together, with the second Complaint part being possibly but not certainly attributable to Chaucer.

${ }_{25}$ Given Skeat's close collaboration with James A. H. Murray, principal editor of what was to become the Oxford English Dictionary, it is likely that Skeat also shaped the definition of virelai given in the October I9I6 fascicle covering $V$-Verificative and forming part of Volume $\mathrm{X}, T i-Z$. The entry defines virelai as a 'song or short lyric piece, of a type originating in France in the I4th century, usu[ally] consisting of short lines arranged in stanzas with only two rhymes, the end-rhyme of one stanza being the chief one of the next.' See $A N e w$ English Dictionary on Historical Principles: Founded Mainly on the Materials Collected by the Philological Society, ed. James A. H. Murray, Io vols (Oxford, I888-I933), X (Part II). Skeat's close collaboration with Murray is chronicled in Lynda Mugglestone's Lost for Words: The Hidden History of the 'Oxford English Dictionary' (London, 2005).

${ }_{26}$ The poems in question are: (i) the poem written on the occasion of Henry V's lords spiritual and temporal paying their homage to him at Kennington (DIMEV 5357); (ii) the poem written following the reburial of Richard II's bones at Westminster (DIMEV 6498); (iii) the poem addressed to Thomas Langley, Bishop of Durham, when he was Chancellor in I406 (DIMEV I290); (iv) the first three stanzas of the ballade and roundel addressed to Henry Somer (DIMEV 5490); (v) the envoy to Prince Henry which concludes the Regiment of Princes; and (vi) the petitionary poem appealing for payment for Hoccleve and two unnamed others addressing Henry $\mathrm{V}$ as 'Victorious king, our lord ful gracious' (DIMEV 6r43). For the text of these poems, see Thomas Hoccleve, Hoccleve's Works: The Minor Poems, ed. Frederick J. Furnivall and I. Gollancz, rev. Jerome Mitchell and A. I. Doyle, EETS es 6I and 73 (Oxford, I970), pp. 39f., 47-9, 58, 59, 61, 62.

27 For Hoccleve's use of the double croisée stanza, see John Burrow, 'Hoccleve and the Middle French poets', in The Long Fifteenth Century: Essays for Douglas Gray, ed. Helen Cooper and Sally Mapstone (Oxford, 1997), pp. 35-49 (pp. 38-40, esp. p. 38 n. 10). Burrow cites Les Règles from Recueil d'arts de Seconde Rhétorique, ed. M. E. Langlois (Paris, 1902), p. 59. 
${ }^{28}$ Chaucerian and Other Pieces, ed. Walter W. Skeat (Oxford, I897), p. 448. In his notes, Skeat (despite having headed the poem 'Virelai') calls it ' $[n]$ ot a true virelay, as the ending -ing does not reappear in the second stanza ... But it is of the nature of a virelay, inasmuch as the rime -ate, which concludes the second stanza, reappears in the third; and so on' (p. 554). ${ }^{29}$ For the construction of MS R.3.19, see Linne R. Mooney, 'Scribes and booklets of Trinity College Cambridge, Manuscripts R.3.19 and R.3.21', in Middle English Poetry: Texts and Traditions: Essays in Honour of Derek Pearsall, ed. A. J. Minnis (Woodbridge, 20oI), pp. 242-66 (p. 242). Mooney's collation and description shows that what was once one booklet of lyrics was separated into two, now comprising fols I-8 and I54-69 of the current foliation. 'Alone walkyng' is now on fol. I60. The poem appears in Chaucer to Spenser: An Anthology of Writings in English, I375-I575, ed. Derek Pearsall (Oxford, 1999), p. 400.

30 Complete Works of Geoffrey Chaucer, ed. Skeat, I, 42. For Woodville and his literary interests, see Dominique T. Hoche, The Reception of Christine de Pizan's 'Fais d'Armes' in Fifteenth-Century England (Lewiston, NY, 2007), pp. 33-64.

${ }^{31}$ John Stevens, Music and Poetry in the Early Tudor Court (London, 196I), pp. 36If.

32 Joannis Rossi antiquarii Warwicensis: Historia regum Anglia (Oxford, I716), pp. 213f.

33 Early Tudor Songs and Carols, ed. John Stevens, Musica Britannica 36 (London, I975), p. I6I.

${ }^{34}$ H. N. MacCracken, 'The Earl of Warwick's virelai', PMLA, 22 (1907), 597-607. On Shirley's copying of the manuscript, see Margaret Connolly, John Shirley: Book Production and the Noble Household in Fifteenth-Century England (Aldershot, 1998), pp. 27-68.

35 In the Index, 'Alone walkyng' is listed as a 'pseudo-Chaucerian virelai-five 8-line tail-rime stanzas' and Beauchamp's poem as 'a virelai, sixty-one lines'. Three of Hoccleve's poems are also labelled as virelais: the poem to Thomas Langley as a 'virelai, three 8-line stanzas', the poem to Henry $\mathrm{V}$ beginning 'The Kyng of Kynges regnyng ouer al' as a 'virelai of five 8-line stanzas, with the same rhyme throughout', and the poem to Henry V beginning 'Victorious kyng' as a 'Virelai to Henry V for money ... three 8-line stanzas'. See The Index of Middle English Verse, ed. Carleton Brown and Rossell Hope Robbins (New York, I943), p. 44 (IMEV 267), p. I25 (IMEV 783), p. 204 (IMEV I288), p. 54I (IMEV 3402), p. 6I7 (IMEV 3854).

${ }^{36}$ Rossell Hope Robbins and John L. Cutler, Supplement to the Index of Middle English Verse (Lexington, Ky, 1965), p. 43 (IMEV 353) and p. 353 (IMEV 3193.5). The lyrics and music of 'As Y lay' are edited by John Stevens, Mediaval Carols, Musica Britannica 4, 2nd rev. edn (London, 1970), p. II2, and see his note on pp. I23f. These identifications remain in the online Digital Index of Middle English Verse in the entries for three of Hoccleve's poems (DIMEV 5357, I290, 6I43), DIMEV's entry for the envoy of Hoccleve's Regiment, 'Alone walkyng' (DIMEV 453), the Warwick poem (DIMEV 2147), and the carol beginning 'As Y lay' (DIMEV 607).

37 John Stevens, in his Music and Poetry in the Early Tudor Court (1961), pp. 212, 219f., accepts the label of virelai for the poem attributed to Beauchamp, though he does not extend the label to 'Sumwhat musyng'. The notes to 'Alone walkyng' in Rossell Hope Robbins's 1952 second edition of his anthology, Secular Lyrics of the XIVth and XVth Centuries (Oxford, I955), reiterate the identification of this poem, four Hoccleve poems, and the Warwick poem as rare surviving examples of Middle English virelais (at p. 279).

38 Rossell Hope Robbins, 'The Middle English court love lyric', in The Interpretation of Medieval Lyric Poetry, ed. W. T. H. Jackson (London, 1980), pp. 205-32 (esp. pp. 219-30, quoting from p. 22I). This article also claims 'Alone walkyng', the Warwick poem, and several of Hoccleve's shorter poems as virelais.

39 On this see Burrow, 'Hoccleve and the Middle French poets'.

${ }^{40}$ Hoccleve's Works: The Minor Poems, pp. 39, 47, 59, 61. 
41 Burrow, 'Hoccleve and the Middle French poets', p. 40.

42 Arthur Piaget, Oton de Grandson: sa vie et ses poésies (Lausanne, 194I), pp. 383-478.

43 'Le Jugement du roy de Behaigne' and 'Remede de Fortune', ed. Wimsatt and Kibler, p. Io.

${ }_{44}$ Jean Froissart, Dits et débats, ed. Anthime Fourrier (Geneva, 1979), pp. 155-70; The Love Debate Poems of Christine de Pizan, ed. Barbara K. Altmann (Gainsville, Fla, 1998); The Poetical Works of Alain Chartier, ed. J. C. Laidlaw (Cambridge, 1974), pp. 158-95, 203-304. 45 Fortunes Stabilnes: Charles of Orleans's English Book of Love: A Critical Edition, ed. Mary-Jo Arn (Binghamton, NY, 1994), pp. I37f.

46 Love Debate Poems, ed. Altmann, p. 75 and n. 127. For Les Règles, see Recueil d'arts de Seconde Rhétorique, ed. Langlois, p. 33.

47 Recueil d'arts de Seconde Rhétorique, ed. Langlois, pp. 33 and 98.

48 Ibid., pp. $225 \mathrm{f}$.

49 Connolly, John Shirley, pp. I4-23.

50 Ibid., p. 29.

51 Ralph Hanna, 'John Shirley and British Library, MS Additional 16165', Studies in Bibliography, 49 (1996), 95-105 (p. 99 and n. Iо).

52 Ibid., p. Ioo.

53 For an introduction to these forms, see Barbara K. Altmann, 'Guillaume de Machaut's lyric poetry', in A Companion to Guillaume de Machaut, ed. Deborah McGrady and Jennifer Bain (Leiden, 20I2), pp. 3II-32 (pp. 32If.).

54 On the subject matter of the French complaintes, see W. A. Davenport, Chaucer: Complaint and Narrative, Chaucer Studies 14 (Cambridge, 1988), pp. $6 f$.

55 Guillaume de Machaut, 'The Fountain of Love' ('La Fonteinne amoureuse') and Two Other Love Vision Poems, ed. and trans. R. Barton Palmer (New York, 1993), pp. 102-45 (lines 235-I034); 'Le Jugement du roy de Behaigne' and 'Remede de Fortune', ed. Wimsatt and Kibler, pp. 218-49 (lines 905-I480); Le Livre dou Voir Dit (The Book of the True Poem), ed. Daniel Leech-Wilkinson, trans. R. Barton Palmer (New York, I998), pp. 402-I2 (lines 5885-6076).

${ }^{56}$ Froissart, Anthology of Lyric and Narrative Poetry, ed. Figg and Barton Palmer, pp. 38-45 (lines 75-202) and pp. 162-95 (lines 1556-2355); Jean Froissart, La Prison amoureuse, ed. Anthime Fourrier (Paris, 1974), pp. I35-42 (lines 3010-219). The Fonteinne amoureuse also has a 'confort' spoken by the lady in the seizain stanza, pp. 206-2I (lines 2207-494).

57 CEuvres poétiques de Christine de Pisan, ed. Maurice Roy, 3 vols (Paris, I886-96), I, 28I-95.

58 Poetical Works of Alain Chartier, ed. Laidlaw, pp. 320-7.

59 Poirion, Le Poète et le prince, pp. 399-408 (quoting from p. 408).

${ }^{60}$ Madeleine Fabin, 'On Chaucer's Anelida and Arcite', MLN, 34 (1919), 266-72 (esp. pp. 270f.).

${ }_{61}$ The editors of Machaut's Remede, James I. Wimsatt and William W. Kibler, note in passing Chaucer's use of this rhyme-scheme in Anelida and Arcite (p. Iо).

${ }^{62}$ Fortunes Stabilnes, ed. Arn, pp. 307-I2.

${ }^{63}$ On the wider relationships between form and content in this sequence, see Mary-Jo Arn, 'Poetic form as a mirror of meaning in the English poems of Charles of Orleans', Philological Quarterly, 69 (1990), 13-28.

${ }^{64}$ Fortunes Stabilnes, ed. Arn, pp. $38 \mathrm{f}$.

${ }_{65}$ Mooney, 'Scribes and booklets', pp. 24I-5.

${ }_{66}$ This ballade has been recently edited by Kathleen Forni in The Chaucerian Apocrypha: A Selection (Kalamazoo, Mich., 2005), pp. $64 \mathrm{f}$.

67 Chaucerian Apocrypha, ed. Forni, p. 60.

${ }^{68}$ In her recent study of tail-rhyme as a form, Rhiannon Purdie notes that 'Alone walkyng' 
and the Findern lyric 'What so men seyn' were copied in what she calls 'graphic tail-rhyme' (i.e. a single stanza split horizontally into two or three columns), suggesting that these lyrics were intended for musical performance: Anglicising Romance: Tail-rhyme and Genre in Medieval English Literature (Cambridge, 2008), p. 79.

${ }^{69}$ Stevens, Music and Poetry, pp. $342 \mathrm{f}$.

${ }^{70}$ Ibid., pp. 355 f., $358 \mathrm{f}$., $362 \mathrm{f}$. There is also a fragmentary and textually corrupt early sixteenthcentury song in the same form edited by John Simons, 'An early sixteenth-century lyric in National Library of Wales MS Peniarth 369b', English Language Notes, 22 (1984-5), I-5.

${ }^{71}$ Ardis Butterfield, 'Mise-en-page in the Troilus manuscripts: Chaucer and French manuscript culture', Huntington Library Quarterly, 58 (1995), 49-80 (p. 80).

${ }^{72}$ John Lydgate, The Temple of Glas, ed. J. Allan Mitchell (Kalamazoo, Mich., 2007). Susan Bianco discusses Lydgate's Temple as a response to the French dit amoreux tradition, including its use of mixed verse-forms, in her 'A black monk in the rose garden: Lydgate and the dit amoureux tradition', Chaucer Review, 34 (1999), 60-8.

${ }^{73}$ Godfried Croenen, Kristen M. Figg, and Andrew Taylor, 'Authorship, patronage, and literary gifts: the books Froissart brought to England in 1395', Journal of the Early Book Society, II (2008), I-42. John Shirley, Beauchamp's secretary, copied French lyric poetry in one of his manuscript anthologies (Cambridge, Trinity College, MS R.3.20) in the early I430s: Margaret Connolly and Yolanda Plumley, 'Crossing the Channel: John Shirley and the circulation of French lyric poetry in England in the early fifteenth century', in Patrons, Authors and Workshops: Books and Book Production in Paris around I40o, ed. Godfried Croenen and Peter Ainsworth (Louvain, 2006), pp. 3II-32.

74 Their signatures and his motto can be seen on fol. I.

75 ESTC citation number Si54I (STC (2nd edn) 7273).

${ }^{76}$ Froissart, Anthology of Lyric and Narrative Poetry, ed. Figg and Barton Palmer, p. x.

77 The contents of Harley MS 443I are discussed and transcribed on the website of the Making of the Queen's Book project: http://www.pizan.lib.ed.ac.uk/index.html.

${ }^{78}$ Sir Thomas Wyatt, The Complete Poems, ed. R. A. Rebholz (New Haven, Conn., 1978), nos. 128, 255, 258; Secular Lyrics of the XIVth and XVth Centuries, ed. Robbins, pp. I38f. On Colyns, see Carol Meale, 'The compiler at work: John Colyns and BL MS Harley 2252', in Manuscripts and Readers in Fifteenth-Century England, ed. Derek Pearsall (Cambridge, 1983), pp. 82-103.

79 ESTC citation number 44096 (STC (2nd edn) I0838.7) and ESTC citation number Sio5573 (STC (2nd edn) 10839). The poem is edited in The British Anthologies, ed. Edward Arber, Io vols (London, I899-I90I), I (The Dunbar Anthology: I40I-I508), pp. I92-216.

${ }^{80}$ On the possible female authorship of this poem and others in the manuscript, see Sarah McNamer, 'Female authors, provincial settings: the re-versing of courtly love in the Findern manuscript', Viator, 22 (199I), 279-310 (see p. 304 for this poem). 'What-so meyn seyn' can also be found in Chaucer to Spenser: An Anthology, ed. Pearsall, p. 402, and in Women's Writing in Middle English, ed. Alexandra Barratt, 2nd edn (Harlow, 2010), pp. 288f.

81 The Poems of William Dunbar, ed. Priscilla Bawcutt, 2 vols, Association for Scottish Literary Studies 27 and 28 (Glasgow, I998), I, I6I.

82 Stevens, Music and Poetry, pp. $358 \mathrm{f}$. 